\title{
HUMAN HEALTH RISK ASSESSMENT APPROACH FOR URBAN PARK DEVELOPMENT
}

\author{
Lalita BHARADWAJ ${ }^{1}$ and Ray MACHIBRODA² \\ College of Nursing, University of Saskatchewan ${ }^{1}$, Machibroda Engineering Ltd. ${ }^{2}$, Saskatoon, \\ Saskatchewan, Canada \\ Received in May 2008 \\ Accepted in July 2008
}

\begin{abstract}
A Human Health Risk Assessment (HHRA) was undertaken for a proposed park development "River Landing", to be constructed along the north bank of the South Saskatchewan River in the City of Saskatoon, Saskatchewan, Canada. The purpose of the HHRA was to determine whether chemical constituents identified at the site, including polycyclic aromatic hydrocarbons (PAHs), petroleum hydrocarbons (PHCs), and toxic and heavy metals, would adversely affect the health of construction workers and potential park users. Although more traditional remediation options were considered, the risk assessment approach was chosen since it represented the best available technology. The HHRA was undertaken using protocols and methodologies proposed and readily accepted by the Canadian Council of Ministers of the Environment (CCME), Health Canada, and the United States Environmental Protection Agency (US EPA). Results of the risk assessment revealed that the magnitude and distribution of the chemicals at the site were such that extensive remediation was not required, and that the site could be developed without any significant restrictions on the proposed use. The assessment revealed that potential exposure to soil constituents would not result in adverse health risk to construction workers involved in park development or future park users.
\end{abstract}

KEY WORDS: chemical contaminants, environmental site assessment, heavy metals, petroleum, polycyclic aromatic hydrocarbons, river landing, soil, toxic metals

The city of Saskatoon is located in central Saskatchewan on the South Saskatchewan River, and is the most populous city in the province with a population of approximately two hundred and thirty thousand (1). Saskatoon is often referred to as the "City of Bridges" for its seven river crossings that connect the east and west areas of the city. The city is engaged in the redevelopment of its south downtown. This redevelopment will result in a revitalization of the City's south downtown with the development of a hotel, a spa, and a park along the South Saskatchewan River.

A Human Health Risk Assessment (HHRA) was undertaken for a proposed park development "River Landing" to be constructed along the north bank of the
South Saskatchewan River. The purpose of the HHRA was to determine whether chemical constituents identified at the site, including polycyclic aromatic hydrocarbons (PAHs), petroleum hydrocarbons (PHCs), and toxic and heavy metals, would adversely affect the health of construction workers and future park users.

Toxic and heavy metals, such as arsenic, cadmium, lead, copper, nickel, and mercury, are important environmental contaminants and raise concern for human health because of their presence in environmental media and the potential for occupational, residential, and recreational exposure (2). Heavy metal toxicity can result in damaged or reduced central nervous system, hematological, 
respiratory, cardiovascular, kidney, and liver function (36). Long-term exposure to heavy metals is associated with degenerative processes that mimic Alzheimer's disease, Parkinson's disease, muscular dystrophy, and multiple sclerosis $(7,8)$. Repeated long-term contact with some metals or their compounds may cause allergies and even cancer (9-11). Exposure to some heavy metals at levels slightly above those naturally occurring in the environment can result in adverse health effects in humans (12-14).

$\mathrm{PAHs}$ are natural products produced by incomplete combustion of organic material (15-17). PAHs are found in tobacco smoke, roasted coffee, in charcoal broiled, barbecued or smoked meats, vegetable oils, and baker's yeast $(15,17)$. They are also found in automobile exhaust creosote, coal tar, and petroleum asphalt $(15,19,20)$. PAHs are found in soil are usually adsorbed on soil particulates, and undergo degradation by soil microorganisms $(15,18,21)$. They can persist in the soil from days to years, depending on the soil adsorbent and the microorganisms present $(15,17)$. They are expected to be immobile in soil and are not readily soluble in water (17).

The toxic effects of PAHs are primarily directed toward tissues that contain proliferating cells (22-24). For example, animal studies indicate that exposure to PAHs can damage cells of the hematopoietic and the lymphoid systems, the rapidly dividing cells of the intestinal epithelium, spermatogonia, and spermatocytes in the testis, and the primary oocytes of the ovary (25-29). Most of these effects have been observed following both chronic oral and parenteral exposures. The primary concern with PAH exposure is the potential for carcinogenicity and immunotoxicity (30). Although animal studies indicate carcinogenic properties, currently there is no direct evidence of their carcinogenic potential in humans (31).

Petroleum hydrocarbons describe a mixture of organic compounds found in or derived from geological substances such as oil, bitumen, and coal. Petroleum products released to the environment, such as gasoline, crude oil, and jet fuel, typically contain hundreds to thousands of compounds in varying proportions, composed primarily of carbon and hydrogen with minor amounts of nitrogen, sulfur, and oxygen (32). The properties of petroleum hydrocarbon contamination in soils vary with the petroleum source and composition, degree of processing, soil type, and weathering. Assessment of human health risks associated with petroleum hydrocarbon contamination in soil is further complicated by the complexity of petroleum products, the variability of sources, and site-specific circumstances (32).

Petroleum hydrocarbon constituents of various petroleum products include aliphatic compounds (straight-chain, branched-chain, and cyclic alkanes and alkenes) and aromatic hydrocarbon compounds $(33,34)$. Despite the large number of hydrocarbons found in petroleum products and the widespread nature of petroleum use and contamination, only a relatively small number of the petroleum hydrocarbons are well characterized for toxicity (32).

The toxicology of petroleum hydrocarbons has been reviewed by the US Total Petroleum Hydrocarbons Working Group (US TPHCWG), which was formed by the US Department of Defense in the mid-1990s $(36,37)$. The TPHCWG defined 14 aromatic and aliphatic sub-fractions of petroleum hydrocarbons. The Petroleum Hydrocarbon Canada Wide Standard (PHC CWS) uses these TPHCWGderived sub-fractions for the assessment of human health and ecological risk. The PHC CWS places these sub-fractions into four practical fractions of straightchain petroleum hydrocarbon constituents. These include Fraction 1 (hydrocarbon chains equivalent to 6 to 10 hydrocarbon bonds; $\mathrm{nC}_{6}$ to $\mathrm{nC}_{10}$ ), Fraction 2 $\left(\mathrm{nC}_{10}\right.$ to $\left.\mathrm{nC}_{16}\right)$, Fraction $3\left(\mathrm{nC}_{16}\right.$ to $\left.\mathrm{nC}_{34}\right)$, and Fraction 4 (greater than $\left.\mathrm{nC}_{35}\right)(28,29)$. Within these sub-fractions the ratio of aromatic and aliphatic constituents is assumed to be $20 / 80(36,37)$.

Exposure to petroleum hydrocarbons leads to a variety of health effects, depending on compounds or mixtures involved, exposure pathway, intensity, frequency, and duration. Only a small number of petroleum hydrocarbons are confirmed human carcinogens (i.e., benzene, benzo(a)pyrene), and most petroleum hydrocarbons are considered as threshold toxins that elicit general narcosis symptoms and are not considered carcinogenic (32).

Human Health Risk Assessment is a process that involves the characterization of the probability of adverse human health effects that are associated with exposure to environmental chemicals (38, 39). Human health risk assessment is not an exact science. Methodologies utilized in HHRA cannot be employed to connect a disease to chemical exposures, nor can they be used to prove that exposures to a particular chemical agent caused a person's disease. Unlike epidemiological studies where the association between past chemical exposures and disease in a subpopulation is evaluated, HHRA is utilized to estimate whether existing or future chemical 
exposures will pose health risks to a large population of people who may reside in a city or a community. The purpose of the HHRA for the proposed park development "River Landing" was to quantify the degree of potential health risk posed by contamination at the subject site. The HHRA was undertaken using protocols and methodologies proposed and readily accepted by the Canadian Council of Ministers of the Environment (CCME), Health Canada, and the United States Environmental Protection Agency (US EPA) (40-42). These guiding principles of risk assessment were utilized to predict the potential for human health risk associated with potential exposure to environmental chemicals as identified in a Phase II Environmental Site Assessment (ESA) for the proposed River Landing Development (43). Although more traditional remediation options were considered, the risk assessment approach was chosen since it represented the best available technology.

The risk assessment included the following elements; hazard identification, receptor characterization, dose response assessment, exposure assessment, and risk characterization. This article outlines and describes the risk assessment approach applied for the City of Saskatoon's proposed park development.

\section{SITE CHARACTERIZATION}

The park development site referred to as "River Landing" is located in the city's core along the west bank of the South Saskatchewan River. The park location is bound by a freeway bridge to the east, a residential district to the west, a former coal-powered electrical generating plant to the north, and the South Saskatchewan River to the south. The development site is comprised of a relatively narrow strip of land; sodcovered and fully landscaped with pedestrian pathways, trees, and shrubs. Underground utility lines including storm sewers, power, natural gas, and fibre optics were present at the site and a pump house, built in the early 1900 's to supply cooling water to the former power plant, was the only building in the development area.

Preliminary studies were conducted at the site over a period of two years and included Phase I and II Environmental Site Assessments (ESAs), geotechnical investigations, and a hazardous materials assessment. Information gathered from the initial ESAs revealed that inorganic materials (toxic and heavy metals), $\mathrm{PHCs}$, and PAHs at concentrations exceeding the
2006 CCME Parkland/Residential (P/R) assessment criteria (44) were randomly distributed in soil fill. The soil fill materials, deposited sometime between 1956 and 1966, reportedly incorporated demolition debris, cinders and ash from a variety of sources, including a former downtown rail yard and the power plant formerly located to the north of the site. Historically, fill materials were utilized to increase the elevation of the site from the west shore of the South Saskatchewan River that confines the south side of the development property.

Four major fill areas (i.e., Area Nos. I through IV, inclusive) were identified on the basis of the ESAs. Chemical constituents measured in the soil fill included toxic and heavy metals (i.e., arsenic, barium, copper, lead, mercury, nickel, selenium, and/or zinc) and PAHs at concentrations exceeding the $2006 \mathrm{CCME}$ $\mathrm{P} / \mathrm{R}$ criteria; and residual hydrocarbons (i.e., Fraction 2, Fraction 3, and Fraction 4) at concentrations exceeding the 2006 Saskatchewan Environment Coarse Grained Residential Soil Criteria (36). Although contaminants were identified at grade, those exhibiting the highest concentrations were typically located at depths ranging from three to approximately five metres below grade. Exceptions to this were PHCs (i.e., Fraction 2, Fraction 3, and/or Fraction 4), which were detected at or near the ground surface.

Even though only four major areas of soil fill were identified at the site, the randomness of the fill deposits suggested that other areas of impacted fill could exist. Further, the lack of information regarding past use of the site suggested that the likelihood of identification of these fill areas was unlikely without extensive, costly investigation. Although remediation of the site could have been accomplished by removing the impacted materials, it was recognized that accurate costs for this option could not be established since the volume of impacted soil was unknown. In light of the above, a site-specific HHRA was employed to determine whether existing chemical constituents at the site would adversely affect the health of potential "River Landing" park users.

\section{RISK ASSESSMENT}

The HHRA included hazard identification, receptor characterization, exposure assessment, dose/response assessment, and risk characterization. The approach taken for each step is described in the subsequent sections. 


\section{Hazard Identification}

The aim of hazard identification, based on human health considerations, was to identify contaminants of potential concern (COPC) at the site. COPC were selected by review and comparison of concentrations of toxic and heavy metals, PAHs, and PHCs measured at the site to the CCME (44) P/R guidelines established to protect human health. Chemical constituents at concentrations exceeding the CCME (44) P/R guidelines were selected for assessment, while those below the guidelines were discarded. In order to provide a substantial safety margin, and an overestimation of potential risk, the maximum chemical concentrations measured at the site were used to assess the potential risks associated with human exposure. Through review of animal and human toxicity data the range of toxic effects attributed to potential exposure to COPC along with the chemical fate and behavior of the COPC in the body and the soil were discussed in this step.

\section{Receptor Characterization}

The second step was the characterization of potential human receptors. In other words, the categories of humans who could potentially be exposed to COPC at the site were identified in this step. Human receptor characteristics such as soil ingestion/ inhalation rates, weight, skin surface area, age, and time spent outdoors were obtained from Richardson (45), summarized, and then subsequently utilized to calculated estimated daily intakes to COPC.

Since the proposed use of the site is a recreational park, three categories of human receptors, namely children, adults, and construction/utility workers, were identified for assessment. Construction workers were defined as individuals involved in development of the site, while the category of children included infants, toddlers, and children as defined by Health Canada (46). The age ranges of the infant (0 to 6 months), toddler ( 7 months to 4 years), and child (5 to 12 years) categories were summed so that a full exposure duration of 12 years was used to assess potential risk. For adults and construction workers, standard receptor characteristics (46) were used, and these individuals were defined as persons aged 18 years and older.

\section{Exposure Assessment}

The exposure assessment involved a description of the likelihood, magnitude, frequency, and duration of exposure to COPC as well as the identification of possible exposure routes. The most likely exposures were: long-term, low-level exposure and direct contact (i.e., ingestion, dermal absorption, inhalation of suspended particulate matter). The maximum contaminant concentrations of COPC identified at the site were used to estimate the magnitude of receptor exposure, or the exposure dose. The bioavailability of COPC, defined (in part) as the fraction of the exposure dose that absorbs into the body and reaches the blood stream of human receptors, was considered $100 \%$ in cases of oral and inhalatory exposure routes. The bioavailability factor of dermal absorption was applied for consideration of the dermal route of exposure.

Realistic recreational exposure scenarios reflective of site-specific human activity patterns at the site were applied to provide an overall evaluation of potential risk of exposure to COPC at the proposed development. It was assumed that an infant would visit the site 12 hours a week, 32 weeks a year (mid March to mid November), a toddler would visit the site 17 hours a week, 32 weeks a year for 4.5 years, and a child would visit the site 20 hours a week, 32 weeks a year for 7 years. An exposure duration of 12 years was used to assess potential risk to children exposed to COPC at the site. For adults, it was assumed they would visit the site 19.25 hours a week, 32 weeks a year (mid March to mid November; when the ground is not likely to be frozen), over a lifetime of 70 years. Construction/utility workers were assumed to be at the site an average of 5 days a week, (40 hours a week), 28 weeks a year for 0.5 years (the duration of time assumed for site development) $(45,47,48)$.

\section{Dose Response Assessment}

The nature of the relationship between the received dose (estimated daily intake) and the probability of an adverse biological response was evaluated in the dose-response step. Estimated daily intakes (EDIs) through each route of exposure were calculated individually for each COPC. EDIs are an approximation of the amount of COPC potentially absorbed into the body through each of the dermal (skin), oral (gastrointestinal), and respiratory (respiratory system) routes of exposure. EDIs were based on maximum measured COPC concentrations and calculated using standard mathematical formulas commonly used in the risk assessment process and established by Health Canada (46).

Toxicity benchmarks, defined as the amount of contaminant exposure that can occur without adverse 
health effects, were also identified in this step. Toxicity benchmarks are generally determined from exposure data obtained from controlled animal and human laboratory tests and/or epidemiological studies. The toxicity benchmarks used in this study were the most restrictive published values available from Health Canada and the USEPA. Toxicity benchmarks are expressed as either Reference Doses (RfD) and/or Slope Factors (SF). RfD $(41,42)$ are determined for threshold toxicants (non-carcinogenic) and SF are determined for non-threshold toxicants (health effect is considered a cancer or a heritable mutation). Toxicity benchmarks were applied with the calculated EDI to mathematical models to derive a risk factor for each COPC. The calculated risk factor for each COPC was ultimately used to characterize potential risk associated with exposure to COPC at the site.

\section{Risk Characterization}

Risk characterization was the final step in the risk assessment process, and involved a determination of a numerical estimation of risk, and the integration of all information gathered through hazard identification, dose response, and exposure assessment to estimate human health risk associated with exposure to contaminants at the development site. Health risks were estimated numerically by comparing EDIs to acceptable toxicity benchmarks. Both EDI and toxicity benchmarks were applied to mathematical models for evaluating risk for both non-threshold (i.e., non-carcinogenic) and threshold (i.e., carcinogenic) toxicants.

For threshold toxicants, the reference dose-hazard quotient methodology was used to quantitatively assess the potential hazards presented by exposure. In this methodology, following the Health Canada (41) and USEPA HHRA Guidelines (42), the human risk estimate was expressed as a Hazard Quotient $(\mathrm{HQ})$. For threshold toxicants, calculated EDIs were expressed as a ratio of acceptable daily intakes or reference doses (RfD). The numerical estimation of risk for non-carcinogenic contaminants $(\mathrm{HQ})$ is defined as follows: $\mathrm{HQ}=\mathrm{EDI}_{\text {soil }} / \mathrm{RFD}_{\text {oral }}+\mathrm{EDI}_{\text {air }} /$ $\mathrm{RFD}_{\text {inhalation }}+\mathrm{EDI}_{\text {dermal }} / \mathrm{RFD}_{\text {dermal }}$. In the case where $R_{\text {dermal }}$ and/or RFD $\mathrm{D}_{\text {inhalational }}$ were not available the $R F D_{\text {oral }}$ value was utilized to calculate $H Q$. A HQ of 0.2 for any threshold toxicant COPC was used to assess acceptable exposure from each individual pathway and was utilized as reference point. Thus for threshold-response contaminants, a $\mathrm{HQ}$ that was less than or equal to 0.2 indicated that the potential exposure was within the degree of exposure that was considered acceptable or "safe".

For carcinogenic contaminants, risk was calculated by multiplying the estimated intake by the appropriate slope factor (SF). The estimate corresponds to an incremental risk of an individual developing cancer over a lifetime as a result of exposure. The calculated risk was then compared to an acceptable benchmark. Target levels of acceptable cancer risk (acceptable benchmarks) vary depending on regulatory agency, but are usually in the range of 1 in 100,000 (i.e., 1 extra cancer death per 100,000 people exposed to a contaminant over their lifetime) to 1 in $1,000,000$ (i.e., 1 extra cancer death per 1 million people exposed to a contaminant over their lifetime). A risk level of $1 \times 10^{-5}$, which is the benchmark level recommended by Health Canada, was used in the risk assessment for comparison to calculated risk values $(41,42)$. Cancer risk levels that were less than $1 \times 10^{-5}$ were viewed as acceptable.

The HQ's for all COPC were well below the target value for all receptors (i.e., 0.2). The risk level calculated for all non-threshold COPC also fell well below the target value $\left(1.0 \times 10^{-5}\right)$ for carcinogenic effects. In other words, the overall assessment strongly suggested that there was no significant health risk posed by non-carcinogenic and/or carcinogenic COPC at the proposed site.

\section{CONCLUSION}

The results of the human health risk assessment indicated that exposure to the maximum concentrations of COPC identified at the site would not result in adverse human health effects to park users. Further, the magnitude and distribution of COPC at the site were such that extensive remediation was not required, and no significant restrictions on the proposed use of the site were recommended.

Construction at the site commenced in 2007 following extensive public review, as well as regulatory approval and permitting by various agencies, including Health Canada and Saskatchewan Environment.

In terms of assessing health risk, utilizing environmental data that is perhaps not complete and where the extent of contamination may not be fully delineated leads to uncertainty in risk assessment. There are several categories of uncertainties associated 
with site-specific risk assessments, and these were addressed in the project. Limitations arise primarily as a result of uncertainties in each of the steps of the risk assessment process. One is the initial selection of substances used to characterize exposures and risk on the basis of sampling data and available toxicity information. Another source of uncertainty is inherent in the toxicity values for each substance used to characterize risk. Additional uncertainties are inherent in exposure assessment for individual substances and individual exposures. These uncertainties arise from the assumptions utilized to estimate exposure concentrations and population intake parameters. Finally, uncertainties are incorporated in risk assessment when exposures to several substances across multiple pathways are summed. To address these uncertainties, conservative methods and assumptions were prescribed to ensure that exposures and risks were not underestimated.

\section{REFERENCES}

1. Statistics Canada. Canada's National Statistics Agency. 2006 Community Profiles. City of Saskatoon, Saskatchewan [displayed 8 May 2008]. Available at http://www.statcan.ca/menu-en.htm

2. Goyer R. Toxic effects of metals. In: Amdur MO, Doull J, Klassen CD, editors. Casarett and Doull's Toxicology: The basic science of poisons. Fourth edition. New York (NY): Pergamon Press; 1991. p. 623-80.

3. Waalkes MP, Fox DA, States JC, Patierno SR, McCabe MJ. Metals and disorders of cell accumulation: Modulation of apoptosis and cell proliferation. Toxicol Sci 2000;56:255-61.

4. International Agency for Research on Cancer (IARC). Monographs on the evaluation of Carcinogenic risks to humans, chromium, nickel and welding. Vol. 49. Lyon: IARC; 1990.

5. Lawrence DA and McCabe MJ, Jr. Immune modulation by toxic metals. In: Goyer RA, Klaassen CD, Waalkes MP, editors. Metal Toxicology. New York (NY): Academic Press; 1995. p. 305-37.

6. Edwards TM, Myers JP. Environmental exposures and gene regulation in disease etiology. Environ Health Perspect 2007;115:1264-70.

7. Brewer GJ. Iron and copper toxicity in diseases of aging, particularly atherosclerosis and Alzheimer's Disease. Exp Biol Med 2007;232:323-35.

8. Verity MA. Nervous system. In: Goyer RA, Klaassen CD, and Waalkes, MP, editors. Metal toxicology. New York (NY): Academic Press; 1995. p. 199-235.

9. Salnikow K, Zhitkovich A. Genetic and epigenetic mechanisms in metal carcinogenesis and co- carcinogenesis: nickel, arsenic and chromium. Chem Res Toxicol 2008;21:28-44.

10. Filipic M, Fatur T, Vudrag M. Molecular Mechanisms of cadmium-induced mutagenicity. Human Exp Toxicol 2006;25:67-77.

11. National Research Council (US). Arsenic in the Drinking Water. Washington (DC): National Academies Press; 1999.

12. Mudipalli A. Lead hepatotoxicity and potential health effects. Indian J Med Res 2007;126:518-27.

13. Bowler RM, Roels HA, Nakagawa S, Drezgic M, Diamond E, Park R, Koller W, Bowler RP, Mergler D, Bouchard M, S mith D, Gwiazda R, Doty RL. Doseeffect relationships between manganese exposure and neurological, neuropsychological and pulmonary function in confined space bridge welders. Occup Environ Med 2007;64:167-77.

14. Coon S, Stark A, Peterson E, Gloi A, Kortsha G, Pounds J, Chettle D, Gorell J. Whole-body lifetime occupational lead exposure and risk of Parkinson's disease. Environ Health Perspect 2006;114:1872-6.

15. Johnsen AR, Karlson U. Diffuse PAH contamination of surface soils: environmental occurrence, bioavailability, and microbial degradation. Appl Microbiol Biotechnol 2007;76:533-43.

16. Rogge WF, Hildemann LM, Mazurek MA, Cass GR. Sources of fine organic aerosol 3. Road dust, tire debris, and organometallic brake lining dust: roads as sources and sinks. Environ Sci Technol 1993;27:1892904.

17. Canadian Council of Ministers of the Environment. Canadian soil quality guidelines for the protection of environmental and human health: Carcinogenic and other PAHs. In: Canadian environmental quality guidelines. Winnipeg (MN): Canadian Council of Ministers of the Environment; 1999.

18. Johnsen AR, Wick LY, Harms H. Principles of microbial PAH-degradation in soil. Environ Pollut 2005;133:7184.

19. Richter P, Pechacek T, Swahn M, Wagman V. Reducing levels of toxic chemicals in cigarette smoke: a new Healthy People 2010 objective. Public Health Rep 2008;123:30-8.

20. Roy TA, Johnson SW, Blackburn GR, Mackerer CR. Estimation of mutagenic and dermal carcinogenic activity of petroleum fractions based on polynuclear aromatic content. In: Cooke M, Dennis AJ, editors. Polynuclear aromatic hydrocarbons: a decade of progress. Columbus (OH): Battelle Press; 1988. p. 809-22.

21. Johnsen, AR, de Lipthay JR, Reichenberg F, Sørensen SJ, Andersen O, Christensen P, Binderup ML, Jacobsen CS. Biodegradation, bioaccessibility and genotoxicity of diffuse polycyclic aromatic hydrocarbon (PAH) pollution at a motorway site. Environ Sci Technol 2006;40:3293-8. 
22. Office on Smoking and Health. Reducing the health consequences of smoking: 25 years of progress: A report of the Surgeon General. DHHS Publication No. CDC 89-8411. Washington, DC: U.S. Department of Health and Human Services, Public Health Service, Centers for Disease Control, Center for Chronic Disease Prevention; 1989. Available at http://www.cdc. gov/tobacco/sgr_1989.htm

23. Weimer TL, Reddy AP, Hartig U, Alexander D, Stamm SC, Miller MR, Baird W, Hendricks J, Bailey G. Influence of beta-naphtoflavone on 7,12-dimethylbenz(a)antracene metabolism, DNA adduction, and tumorigenicity in rainbow trout. Toxicol Sci 2000;57:217-28.

24. Perreault SD, Rubes J, Robbins WA, Evenson DP, Selevan SG. Evaluation of aneuploidy and DNA damage in human spermatozoa: applications in field studies. Andrologia 2000;32:247-54.

25. Yusuf N, Timares L, Seibert M, Xu H, Elmets CA. Acquired and innate immunity to polyaromatic hydrocarbons. Toxicol Appl Pharmacol 2007;224:30812.

26. Izwaw H, Kohara M, Watanabe G, Taya K, Sagai M. Diesel exhaust particle toxicity on spermatogenesis in the mouse is aryl hydrocarbon receptor dependent. J Reprod Dev 2007;53:1069-78.

27. Shiverick KT, Salafia C. Cigarette smoking and pregnancy I: ovarian, uterine and placental effects. Placenta 1999;20:265-72.

28. Weber LP, Janz DM. Effect of beta-naphthoflavone and dimethylbenz(a)anthracene on apoptosis and HSP70 expression in juvenile channel catfish (lctalururs punctatus) ovary. Aquat Toxicol 2001;54:39-50.

29. Gear RB, Yan M, Schneider J, Succop P, Heffelfinger SC, Clegg DJ. Charles river Sprague Dawley rats lack early age-dependent susceptibility to DMBA-induced mammary carcinogenesis. Int J Biol Sci 2007;3:40816.

30. Anderson C, Hehr A, Robbins R, Hasan R, Athar M, Mukhtar $\mathrm{H}$, Elmets CA. Metabolic requirements for induction of contact hypersensitivity to immunotoxic polyaromatic hydrocarbons. J Immunol 1995;155:35307.

31. International Agency for Research on Cancer (IARC). Monographs on the evaluation of carcinogenic risks to humans. Polynuclear aromatic compounds. Part 1. Chemical, environmental and experimental data. Vol 32. Lyon: World Health Organization; 1983. p. 431-45.

32. Canadian Council of Ministers of the Environment. Canadian soil quality guidelines for carcinogenic and other polycyclic aromatic hydrocarbons (Environmental health effects). Scientific supporting document 2008. [displayed 5 April 2008]. Available at http://www.ccme/ ca/assets/pdf/pah_soqg_ssd_1401.pdf

33. Van Hamme JD, Singh A, Ward OP. Recent Advances in Petroleum Microbiology. Microbiol Mol Biol Rev 2003;67:503-49.
34. Leahy JG, Colwell RR. Microbial degradation of hydrocarbons in the environment. Microbiol Rev 1990;54:305-15.

35. Colwell RR, Walker JD. Ecological aspects of microbial degradation of petroleum in the marine environment. Crit Rev Microbiol 1977;5:423-45.

36. Total Petroleum Hydrocarbon Criteria Working Group. Selection of representative TPH fractions based on fate and transport considerations. Volume 3. Total Petroleum Hydrocarbon Criteria Working Group Series. Amherst (MA): Amherst Scientific Publishing; 1997.

37. Total Petroleum Hydrocarbon Criteria Working Group. Development of fraction specific reference doses (RfDs) and reference concentrations (RfCs) for total petroleum hydrocarbons. Volume 4. Total Petroleum Hydrocaron Criteria Working Group Series. Amherst (MA): Amherst Scientific Publishers; 1997.

38. Health Canada. 1994. Human health risk assessment for Priority Substances. Ottawa (ONT): Environment Canada; 1994. Catalogue No. En40-215/41E.

39. Scala R. Risk assessment. In: Amdur MO, Doull J, Klaassen CD, editors. Casarett and Doull's toxicology: the basic science of poisons. Fourth Edition. New York (NY): Pergamon Press; 1991. p. 985-95.

40. Canadian Council of Ministers of the Environment. A protocol for the derivation of environmental and human health soil quality guidelines. March 1996. Report No. CCME EPC-101E, CCME.

41. Health Canada. Canadian environmental protection act human health risk assessment for priority substances. Ottawa (ONT): Canadian cataloguing in publication data; 1994. Catalogue No. En40-215/41E.

42. United States Environmental Protection Agency (US EPA). Risk assessment guidance for superfund. Volume I. Human health evaluation manual (Part A). Washington (DC): Office of Emergency and Remedial Response; 1989. Report No. EPA/540/1-89/002.

43. P. Machibroda Engineering Limited (PMEL). Additional drilling investigation river. Landing phase two development Saskatoon, Saskatchewan 2006. Report No. PMEL File. S06-5662.1.

44. Canadian Council of Ministers of the Environment. Canadian soil quality guidelines for the protection of environmental and human health. Summary tables update 6.02 November 2006 [displayed 5 April 2007] Available at http://w3.ualg.pt/člnunes/Textosdeapoio/ Disciplinas/SPS/Canadian\%20Soil\%20Standards_ \%20Update_I2006.pdf

45. Richardson GM. Compendium of Canadian human exposure factors for risk assessment. Ottawa (ONT): O'Connor Associates Environmental Incorporated; 1997.

46. Health Canada. Environmental and workplace health. Human health risk assessment guidance materials. Health Canada Federal Contaminated Sites Guidance on Human Health Risk Assessment in Canada Part I 
[displayed 7 January 2008]. Available at http://www.hcsc.gc.ca/ewh-semt/contamsite/risk-risque-eng.php.

47. United States Environmental Protection Agency (US EPA). Exposure factors handbook. Volume I: General factors; Volume II: Food ingestion factors; Volume III: Activity factors. Washington (DC): 1997. Report No. EPA/600/P-95/002Fa.

48. United States Environmental Protection Agency (US
EPA). Child specific exposure factors handbook. Washington (DC): Office of Research and Development, National Center for Environmental Assessment; 2002. Report No. USEPA EPA-600-P-00-002B. 


\section{Sažetak}

\section{PRISTUP PROCJENI ZDRAVSTVENOGA RIZIKA ZA LJUDE PRILIKOM IZGRADNJE GRADSKOGA} PARKA

Napravljena je procjena zdravstvenoga rizika za ljude (izv. human health risk assessment, HHRA) za projekt gradskoga parka "River Landing" koji bi se trebao izgraditi duž sjeverne obale rijeke South Saskatchewan u Saskatoonu, saveznoj državi Saskatchewan u Kanadi. Svrha je procjene bila utvrditi mogu li kemijski spojevi zatečeni na gradilištu, uključujući policikličke aromatske ugljikovodike, naftne ugljikovodike te toksične i teške metale, štetno utjecati na zdravlje građevinskih radnika i korisnika parka. Premda je razmotrena i uporaba tradicionalnijih metoda sanacije, izabran je ovaj pristup procjeni rizika zbog toga što rabi najbolju dostupnu tehnologiju. Procjena rizika provedena je prema protokolima i metodama koje je odmah usvojio Kanadski savjet ministara za zaštitu okoliša (izv. Canadian Council of Ministers of the Environment, CCME), savezni ured za zdravlje Health Canada te Agencija za zaštitu okoliša Sjedinjenih Država (izv. United States Environmental Protection Agency, US EPA). Procjena rizika pokazala je da količina i rasprostranjenost kemikalija na gradilištu nisu takvi da zahtijevaju opsežniju sanaciju, te da se lokacija može izgraditi bez značajnih ograničenja u namjeni. Procjenom je također utvrđeno da eventualno izlaganje sastavnicama tla neće dovesti do štetnih posljedica za zdravlje građevinskih radnika koji rade na parku, a niti za buduće korisnike parka.

KLJUČNE RIJEČI: ekološka procjena građevinske lokacije, kemijski onečišćivači, naftni ugljikovodici, odmorište na rijeci, policiklički aromatski ugljikovodici, teški metali, tlo, toksični metali

CORRESPONDING AUTHOR:

Lalita Bharadwaj, $\mathrm{PhD}$

College of Nursing, University of Saskatchewan

107 Wiggins Road, Saskatoon, Saskatchewan,

S7N 5E5, CANADA

E-mail: lalita.bharadwaj@usask.ca 